\title{
Pulmonary Fibrosis in Children
}

\author{
Nadia Nathan ${ }^{1,2, *} \mathbb{1}$, Chiara Sileo ${ }^{3}$, Guillaume Thouvenin $^{1}$, Laura Berdah ${ }^{1}$, Céline Delestrain ${ }^{1}$, \\ Effrosyne Manali ${ }^{4}$, Spyros Papiris ${ }^{4}$, Pierre-Louis Léger ${ }^{5}$, Hubert Ducou le Pointe ${ }^{3}$, \\ Aurore Coulomb $1^{\prime}$ Hermine $^{6}$ and Annick Clement ${ }^{1,2}$ \\ 1 Pediatric Pulmonology Department, Reference Center for Rare Lung Diseases (RespiRare), \\ Armand Trousseau Hospital, Assistance Publique Hôpitaux de Paris (AP-HP), 75012 Paris, France \\ 2 Inserm UMR_S933, Sorbonne Université, 75012 Paris, France \\ 3 Pediatric Radiology Department, Armand Trousseau Hospital, AP-HP, 75012 Paris, France \\ 4 2nd Pulmonary Medicine Department, General University Hospital “Attikon", Medical School, \\ National and Kapodistrian University of Athens, 12462 Athens, Greece \\ 5 Intensive Care Unit, Armand Trousseau Hospital, AP-HP, 75012 Paris, France \\ 6 Pathology Department, Armand Trousseau Hospital, AP-HP, 75012 Paris, France \\ * Correspondence: nadia.nathan@aphp.fr; Tel./Fax: +33-(1)-44-73-66-18
}

Received: 16 July 2019; Accepted: 21 August 2019; Published: 28 August 2019

\begin{abstract}
Pulmonary fibrosis (PF) is a very rare condition in children, which may be observed in specific forms of interstitial lung disease. None of the clinical, radiological, or histological descriptions used for PF diagnosis in adult patients, especially in situations of idiopathic PF, can apply to pediatric situations. This observation supports the view that PF expression may differ with age and, most likely, may cover distinct entities. The present review aims at summarizing the current understanding of PF pathophysiology in children and identifying suitable diagnostic criteria.
\end{abstract}

Keywords: pulmonary fibrosis; interstitial lung disease; children; usual interstitial pneumonia; nonspecific interstitial pneumonia

\section{Introduction}

In children, pulmonary fibrosis (PF) is a very rare condition, which has been sparsely described in specific forms of children's interstitial lung disease (chILD). chILD has a reported incidence of 1-4 per millions of children and covers heterogeneous disorders in the immunocompetent host, such as surfactant disorders, pulmonary alveolar proteinosis (PAP), alveolar hemorrhage, neuroendocrine cell hyperplasia of infancy (NEHI), sarcoidosis, lung involvement of connective tissue diseases, hypersensitivity pneumonitis, and more than $25 \%$ of undefined chILD. Various classifications have been proposed so far based on clinical or histological features [1-6]. However, none of them have identified PF as a distinct chILD entity, and unlike adult PF, no PF diagnosis criteria have been proposed in children.

In adults, the most frequent adult PF, but also the most severe, is idiopathic PF (IPF), diagnosed on a usual interstitial pneumonia (UIP) pattern. UIP is characterized on high resolution computed tomography (HRCT) scan by honeycombing together with traction bronchiectasis and a subpleural and lower lobe repartition of the lesions [7-9]. On lung tissues, UIP is characterized by dense fibrosis with architectural distortion, predominant subpleural and/or paraseptal distribution of fibrosis, hyperplasic type 2 alveolar epithelial cells (AEC2), and fibroblastic foci with extracellular matrix (ECM) deposition in the absence of features suggesting an alternative diagnosis. Nonspecific interstitial pneumonia (NSIP) can also be associated with PF. NSIP is described on lung HRCT scans as a combination of ground-glass opacities (GGOs) and reticulations with no obvious gradient. In NSIP, basal GGOs tend to predominate over reticular opacities, with traction bronchiectasis only in advanced fibrotic-type 
disease [8]. On lung biopsy, NSIP is characterized by the absence of parenchymal distortion, a diffuse thickening of alveolar walls, inflammatory cell recruitment, mild fibroblastic activation, mild collagen deposits, and a relative respect of the capillary bed [9-11].

According to pediatric publications on chILD pathophysiology, lung fibrosis is a "destruction of pulmonary architecture caused by an abnormal wound repair response that ultimately leads to scar formation, organ malfunction, disruption of gas exchange, and respiratory failure" [12]. This definition mixes clinical, functional, and pathological issues of lung fibrosis and highlights pediatricians' confusion over lung fibrosis's definition. This review aims to explore the current knowledge on PF epidemiology, patterns, evolutive aspects through age, and natural history.

\section{PF Reports in Pediatric Population}

The prevalence or incidence of childhood PF seems impossible to evaluate. More than a decade ago, in the major publication on chILD histopathological classification, Deutsch et al. observed only one patient with PF out of a population of 99 pediatric patients with chILD [1]. In this 22-month-old patient with a surfactant disorder due to SFTPC mutation, the author described an NSIP pattern, together with Periodic acid-Schiff (PAS)-positive staining, consistent with alveolar proteinosis. The association of PF in children with surfactant disorders was also highlighted by Dishop in 2011, who suggested that PF, characterized by the presence of honeycombing, could be an end-stage complication of specific ILD conditions in older children and adolescents [13]. The lung biopsy of a teenage patient with idiopathic juvenile arthritis presenting a fibrosing NSIP pattern on the biopsy was provided as an example of PF. The author also suggested that surfactant disorders and hypersensitivity pneumonitis could be predisposing conditions for PF evolution. Later on, the rarity of PF in children was confirmed by a large study by Rice et al., who reviewed the lung biopsies of 211 patients with various forms of chILD [4]. A PF pattern was found in only $2 \%$ of the 93 patients aged under 2 years and in $7 \%$ of the 118 patients aged 2-18 years. NSIP was the most prevalent histologic pattern, but the authors highlighted that most pediatric patients harbor coexisting histologic patterns of ILD within the same sample, such as alveolar proteinosis, desquamative interstitial pneumonia (DIP), or follicular bronchiolitis.

Based on these very few pediatric studies, it seems that adult radiologic and histologic lung fibrosis patterns partially fail to precisely describe pediatric PF lesions and that UIP, the most common aspect of IPF, is exceptionally or never observed in childhood. Thus, a critical question is whether the natural history of childhood PF can evolve towards IPF.

As a reference center for rare lung diseases, we locally reviewed the cases of chILD who benefited from a lung sample through biopsy or autopsy. Among 119 patients, 44 underwent a lung biopsy or autopsy and only 10 were suspected of PF (Table 1). After review, only five (3\%) patients were considered to meet PF criteria (i.e., fibroblast recruitment with ECM deposition). Their clinical data, HRCT scans, and lung tissue histologic analyses are provided in Table 2 and Figure 1.

Table 1. Suspected cases of pulmonary fibrosis (PF) in the children's interstitial lung disease (chILD) cohort of Armand Trousseau Hospital.

\begin{tabular}{cccc}
\hline chILD Condition & Number of Patients & $\begin{array}{c}\text { Number of Patients with } \\
\text { Available Lung Samples }\end{array}$ & $\begin{array}{c}\text { Number of Cases with } \\
\text { Suspected PF }\end{array}$ \\
\hline Surfactant disorders & 17 & 5 & 2 \\
\hline $\begin{array}{c}\text { Autoinflammatory and } \\
\text { systemic disorders }\end{array}$ & 6 & 6 & 1 \\
\hline Developmental disorders & 8 & 8 & 0 \\
\hline Others & 88 & 25 & 7 \\
\hline Total & $\mathbf{1 1 9}$ & $\mathbf{4 4}$ & $\mathbf{1 0}$ \\
\hline
\end{tabular}


Table 2. Clinical data and outcomes of five patients of the Trousseau Hospital chILD cohort with lung fibrosis.

\begin{tabular}{cccc}
\hline Patient Number & Clinical Presentation & Treatment & Outcome \\
\hline $1[14,15]$ & 6-year-old girl, $A B C A 3$-related disease & HCQ, azithromycin & Diffuse fibrosing ILD at age 26 \\
\hline $2[16]$ & 8-year-old boy, TMEM173-related disease & $\begin{array}{c}\text { Corticosteroid pulses, oral corticosteroids, } \\
\text { ruxolitinib at age 13. }\end{array}$ & $\begin{array}{c}\text { Lung transplantation at age 14, died at age 16 } \\
\text { after second lung transplantation }\end{array}$ \\
\hline 3 & 3-year-old boy, undefined chILD & Corticosteroids & Died at age 3 from respiratory failure \\
\hline 4 & 2-year-old girl, undefined chILD & $\begin{array}{c}\text { Corticosteroid pulses, oral corticosteroids, } \\
\text { azithromycin, immunosuppressive drugs }\end{array}$ & Died at age 2 from respiratory failure \\
\hline 5 & 2-year-old girl, undefined chILD & Corticosteroid pulses, oral corticosteroids, \\
azithromycin
\end{tabular}

Abbreviations: chILD, children interstitial lung disease; HCQ, hydroxychloroquine. 


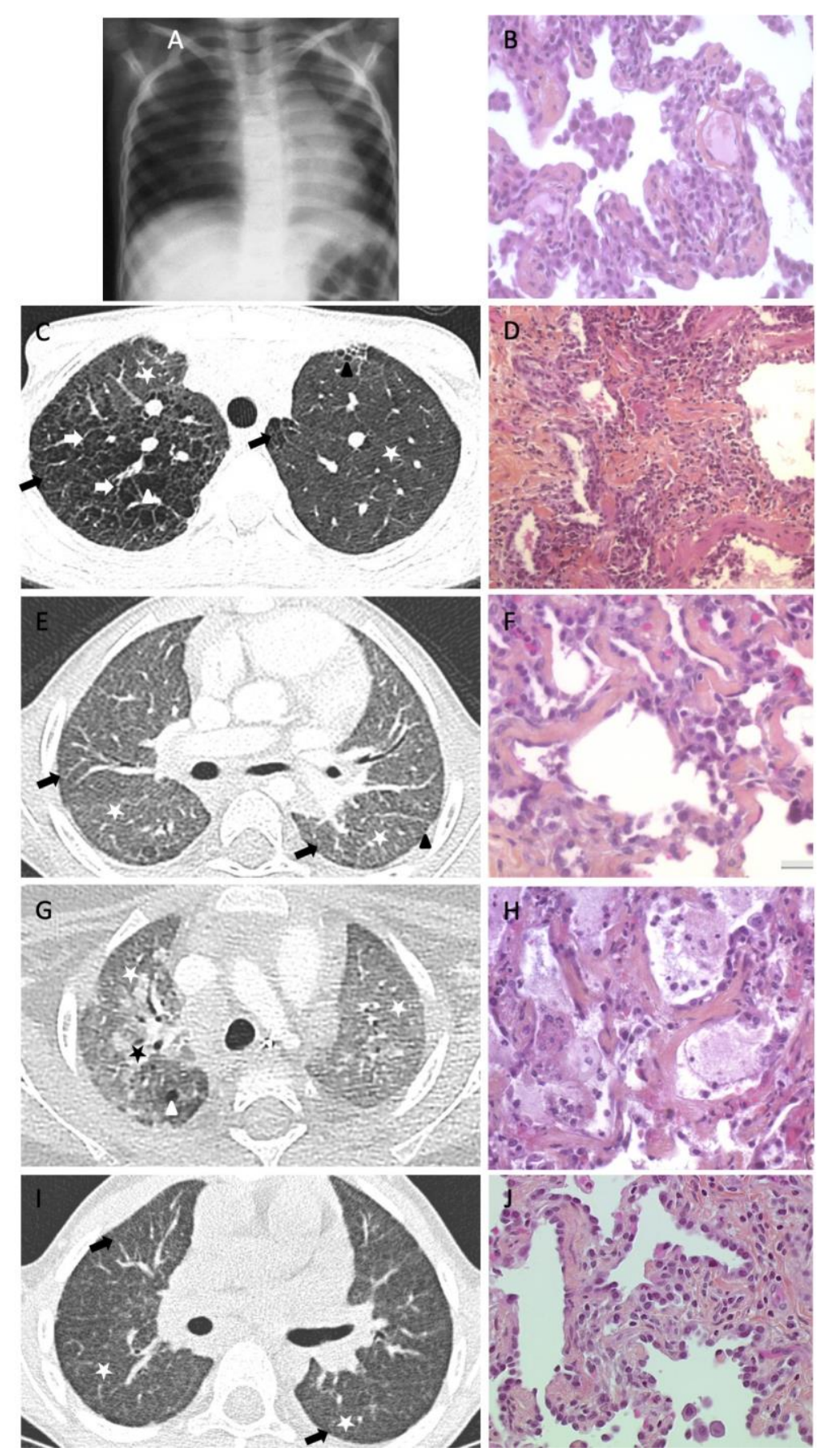

Figure 1. Pulmonary fibrosis examples in children. Panels A and B: Patient 1. (A) Chest X-ray: diffuse repartition of ground-glass opacities (GGOs). (B) Lung biopsy at age 6: no or mild parenchymal distortion, diffuse thickening of the alveolar walls, hyperplasic alveolar epithelial cells (AECs), inflammatory cell recruitment, mild fibroblasts activation, and mild collagen deposition. Panels $\mathrm{C}$ and D: Patient 2. (C) Transverse HRCT scan obtained at the level of the upper lobes: diffuse repartition of mild GGOs (white stars), reticulations (with interlobular septal thickening (white arrows) and intralobular lines (black arrows)), and numerous cystic lesions (white arrowheads) with focal left subpleural honeycombing (black arrowhead). Reticulations and cystic lesions are wider on the right. 
(D) Lung biopsy: parenchymal distortion, inflammatory cell recruitment, lymphoid nodules, and mild collagen and severe elastic fiber deposition. Panels E and F: Patient 3. (E) Transverse HRCT scan obtained under the level of the carina: diffuse repartition of GGOs (white stars), moderate reticulations (with intralobular lines (black arrows)), and few subpleural cystic lesions (black arrowhead). (F) Lung autopsy: no parenchymal distortion, diffuse thickening of the alveolar walls, hyperplasic AECs, mild inflammatory cell recruitment, and elastic fiber deposition. Panels G and H: Patient 4. (G) Transverse HRCT scan obtained at the level of the upper lobes: diffuse repartition of severe GGOs (white stars), consolidations (black star), and few cystic lesions (white arrowhead). (H) Postmortem biopsy: no parenchymal distortion, diffuse thickening of the alveolar walls, hyperplasic AECs, mild inflammatory cell recruitment, elastic fiber deposition, and moderate alveolar proteinosis: intra-alveolar deposit with giant cells and liproproteic material. Panels I and J: Patient 5. (I) HRCT scan obtained at the level of the lung bases: diffuse and homogeneous repartition of GGOs (white stars) with reticulations (with intralobular lines (black arrows)). (J) Lung biopsy: no parenchymal distortion, diffuse thickening of the alveolar walls, hyperplasic AECs, and moderate inflammatory cell recruitment.

\section{Lessons from Surfactant Disorders}

In the past years, for adult cases of surfactant disorders, mainly surfactant protein (SP)-C, ATP-binding cassette subfamily A member 3 (ABCA3), and NK2 homeobox 1 (NKX2-1), related diseases have been reported in sporadic or family forms of ILD. These conditions, known to be more prevalent in children than adults, are very interesting study models of lung fibrosis progression through age. The literature provides various examples of CT scan and lung tissue analyses from pediatric patients with such disorders, but very few long-term follow-ups of these patients have been reported. SP-A-related disorders have been mainly described in adults, with one pediatric case, however, in a large kindred [17,18].

In infants and childhood patients with surfactant disorders, lung imaging is heterogeneous, but diffuse GGOs and reticulations are a constant feature in severe cases. Cystic lesions, mostly with subpleural repartition, seem to appear secondarily, most likely as the consequence of a parenchymal loss of elasticity and compliance [19-21]. The histologic pattern of surfactant disorders is usually characteristic, with a forefront thickening of the alveolar walls; hyperplasic AEC2 bulging into the alveolar space; intramacrophagic alveolar proteinosis filling the alveolar space, sometimes associated with cholesterol clefts; and inflammatory cell recruitment. Collagen and ECM deposition are absent or moderate, as well as fibroblastic recruitment. There is usually no parenchymal destruction. Altogether, this histologic pattern is, in most cases, mimicking NSIP with additional features of alveolar proteinosis [22]. In the collaborative European network for chILD, among 24 patients with homozygous or compound heterozygous $A B C A 3$ mutations retrieved from the Kids Lung Register experience, NSIP, DIP, and chronic pneumonitis in infancy were the most common histologic patterns, and only one case of interstitial fibrosis pattern was reported in a patient whose lung disease was fatal in infancy [23].

In adult patients, SP-C, ABCA3, and SP-A disorders have been reported [24]. In SP-C and ABCA3 cases, lung imaging found subpleural predominance of reticulations and cystic lesions and few or no GGOs. This atypical aspect was further described as "combined pulmonary fibrosis and emphysema" (CPFE) by Cottin et al., who reported a 32-year-old patient with the most frequent p.Ile73Thr SFTPC mutation [25]. CPFE was further reported in adult patients with SP-C disorders, including a large kindred with patients aged 14-68 years at diagnosis, all presenting with UIP pattern [26]. Epaud et al. also reported a 41-year-old patient with CPFE related to biallelic $A B C A 3$ mutations with a life-long history of lung disease [27]. In these adult reports of surfactant disorders, the lung tissue analysis was characterized by parenchymal destruction, hyperplasic AEC2, but also fibroblast foci and elastic fiber deposition. Thus, both imaging and histologic pattern evocated UIP despite exceptional honeycombing. Interestingly, in large next generation sequencing (NGS) or whole exome sequencing (WES) studies including IPF patients with a histologic UIP attested by the ATS/ERS criteria (2011), a few SFTPC and biallelic $A B C A 3$ mutations were identified $[11,28]$. SP-A-related disorders were more recently associated with ILD $[17,18,28,29]$. They were alternatively associated on HRCT scans and histology of 
the lung with UIP, NSIP, and even DIP patterns [30]. Altogether, even if IPF terminology is evocated in adult forms of surfactant-related diseases, it seems that the histologic patterns cannot be defined only as UIP.

Little is known about surfactant disorder progression from childhood to adulthood. A few reports of family cases including children and adult presentations have been reported and even fewer descriptions of a single patient's evolution over time. Abou Taam et al. described up to 13 years of HRCT scan follow-up in a large family with the most common SFTPC mutation [31]. The authors clearly showed that GGO intensity and extension were decreasing over time, whereas septal thickening, subpleural and intraparenchymal cysts, and even honeycombing were appearing and increasing with age. A comparative pediatric and adult histologic description in a single family with SFTPC mutation was first provided by Thomas et al. [32]. The authors showed that the infant and the adult patients harbored different patterns: cellular thickening and intra-alveolar granular material consistent with cellular NSIP in the infant tissue, compared with a UIP pattern with fibroblast foci, architectural distortion, and metaplastic epithelium in the adult biopsy. This heterogeneity was also suggested by other family studies of kindred with SFTPC mutations [33,34]. One family with patients presenting homozygous $A B C A 3$ mutations aged 16-52 years at diagnosis was also described [35]. In this family, with a late onset of the disease, all the patients showed evidence of mild fibrosis on HRCT scans with architectural distortion, intra- and interlobular thickening, apical honeycombing, and no GGOs. However, the lung tissue analysis of the youngest patient showed a relative architectural conservation and a typical childhood pattern of surfactant disorders with inflammatory cell recruitment and multinucleated cells with cholesterol clefts and mild alveolar proteinosis coexisting with fibroblast foci or smooth muscle proliferation and bronchiolar metaplasia, in favor of a mixed NSIP/DIP/UIP pattern. Finally, the 20-year evolution of a patient with $A B C A 3$ mutations was described, with available lung histology at age 6 and 26 years [14]. The childhood lung biopsy showed AEC2 hyperplasia, diffuse septal thickening, and few intra-alveolar macrophages with no fibrosis and a similar appearance worsened by fibrosis features in adulthood. Rare family cases of brain-lung-thyroid syndrome related to NKX2-1 mutation have been described so far. We recently described a family with a lung involvement of the disease, the child presenting with a dense GGO pattern on HRCT scan and the mother with a fibrosing evolution at age 28 years [36]. Among a large cohort study of patients with NKX2-1 mutations, the lung HRCT scan pattern evolution was shown in a single patient over 9 years, revealing a decrease of GGOs with no cysts or reticulations [37]. Finally, in a large family with SFTPA1 mutations associated with PF and adenocarcinoma of the lung, the histology analysis of adult patients was described as UIP pattern, whereas the lung analysis of one infant who died at 9 months of age from lung disease showed a mixed NSIP and DIP pattern [18]. Regarding these isolated reports, it seems quite impossible to define evidence on the pattern's evolution. However, some specificities of PF natural history could be highlighted: in childhood, GGO seems predominant, together with mixed histologic patterns, and in adulthood, septal thickening, traction cysts, and honeycombing can appear, mostly related to UIP or probable UIP patterns.

\section{Other Situations of PF Evolution through Age}

Recently, autoinflammatory disorders such as TMEM173 mutations (STING activation) and COPA syndrome appeared as newcomers in the chILD's field and provided other examples of ILD evolution through age. More children than adults have been described. In children, the typical presentation is an ILD with a diffuse repartition of the lesions, GGOs, reticulations, but also an early appearance of cystic lesions and traction bronchiectasis [38,39]. A family case of STING disease was provided by Picard et al., who reported CT scans and lung biopsies from the affected child and mother [16]. The pediatric HRCT scan showed more GGOs, more reticulations, and less traction bronchiectasis than the adult case. Both had cystic lesions and emphysematous lesions with upper lobe predominance. Lung tissues of both patients were available and both presented various degrees of fibrosis. The parenchymal destruction was mild in the child and major in the mother; inflammatory cell recruitment was important in the 
child's parenchyma and mild in the mother's, in whom the ECM and elastic fiber deposition was predominant. Both showed lymphoid nodules that evocated the autoinflammatory etiology of the ILD. In COPA syndrome, the lung involvement is almost a constant feature. The princeps publication reported no fibrosis in patients with ILD or in patients with alveolar hemorrhage [40]. However, more HRCT scan aspects of the patients have been described since, some with fibrosis, especially in a 12-year-old patient for whom the authors provided a 3-year-old follow-up of the HRCT scan: over time, GGOs that were initially important seemed to decrease, whereas reticulations and cystic lesions were increasing [41]. This was further confirmed by a COPA syndrome study: the authors reported the HRCT scan aspects of 11 patients, in whom parenchymal cysts of variable distribution were the most frequent feature, followed by GGOs and nodules. In only one patient were HRCT scan aspects considered to be PF. Lung tissue analysis was available for 10 patients and showed a non-UIP interstitial fibrosis in only 2 patients [42]. These reports, combined with our experience with STING and COPA syndrome, suggest that parenchymal distortion and cysts can also be present at the early stages of pediatric ILD and can evolve towards PF, mainly during the second decade (personal data).

\section{Summary of Childhood and Adult PF Comparison}

Altogether, despite the paucity of described cases, current information suggests that two distinct situations may exist: diseases with onset in infancy/childhood and adult-onset diseases. The first one presents with a cellular NSIP pattern and seems to evolve with age towards a paucicellular NSIP pattern with features of UIP or probable UIP, such as fibroblast foci or smooth muscle proliferation. On the other hand, disorders with adult or late-childhood onset seem to present with a UIP or probable UIP pattern and less frequently with fibrosing NSIP [43]. Thus, although the term PF is used in children, it seems to refer to a different pattern than in adults, with more inflammatory cell recruitment and less fibroblast recruitment and ECM deposition (Table 3). The observed pattern in children would probably not have been named "fibrosis" by adult pathologists. Thus, it seems obvious that, even when being of the same genetic origin, the pathophysiological pathways of PF in children and adults are different.

Table 3. Childhood pathological findings of pulmonary fibrosis compared to adults.

\begin{tabular}{ccc}
\hline & Pediatric PF & Adult IPF/Probable IPF \\
\hline Parenchymal distortion & + & +++ \\
\hline Cellular recruitment & +++ & + \\
\hline Extracellular matrix deposition & + & +++ \\
\hline Fibroblast foci & $+/-$ & +++ \\
\hline Honeycombing & $+/-$ & +++ \\
\hline Global pattern & $\begin{array}{c}\text { Predominant NSIP mixed with } \\
\text { alveolar proteinosis, DIP, and } \\
\text { follicular bronchiolitis }\end{array}$ & Predominant UIP pattern \\
\hline
\end{tabular}

+/-: absent or moderate, +: moderate, +++ : important; Abbreviations: PF, pulmonary fibrosis; IPF, idiopathic pulmonary fibrosis; NSIP, nonspecific interstitial pneumonia; DIP, desquamative interstitial pneumonia; UIP, usual interstitial pneumonia.

\section{Pathophysiology}

The heterogeneity of ILD phenotypes, even in the same family, has been well described in surfactant disorders. However, the reason why individuals with a pathogenic mutation are able to remain asymptomatic for decades remains unknown. The role of environmental triggers, especially viral exposure in infancy, has been suggested. One could hypothesize that the pathophysiologic fibrosing process may be different when occurring on a lung in development and growth versus on grown-up, mature, and moreover senescent lung tissue. Environmental exposures may also be different in children, in whom viral infections have been suggested as potential triggers of genetically 
predisposed ILD, whereas tobacco smoking and occupational exposures are the main suggested triggers in IPF [44-46].

At the cellular level, the pathophysiology of lung fibrosis is supposed to be initiated by repeated lung aggression that impairs the functioning of three main cellular types: AEC2, fibroblasts, and alveolar macrophages. Prolonged denudation of the basement membrane after injury contributes to altered interactions between AECs and mesenchymal cells, resulting in profound modifications of cell functions with imbalanced production of polypeptide mediators, including cytokines, growth factors, oxidants, and proteases [47-49]. The lung lesions induce endoplasmic reticulum (ER) stress of the AEC2 that can promote cell death or cell reprogramming. Type 1 macrophages are activated toward the alveolar space. Fibroblasts as well are activated, and they proliferate into the alveolar epithelium and differentiate into a myofibroblastic pattern. Epithelial reprogramming can lead to mesenchymal differentiation, which is called epithelial-to-mesenchymal transition. In parallel, microvascular disorders are observed with local vascular leaks and intravascular coagulation with fibrin clot deposition. Altogether, an increase of the alveolar epithelium thickness is observed, constituted by cellular and ECM deposition. Ultimately, an alveolar collapse that affects the alveolar structure is observed, with re-epithelialization phenomena [50]. This pathway, which is well described in adults, has not been evaluated in children. The few observations that have been previously described sustain that, in children, the fibrosing process could end at the cellular deposition stage without evolving, in most cases, towards ECM accumulation and alveolar collapse. This hypothesis matches with what has been observed in cell and mice models of surfactant disorders, which are associated with increased ER stress, AEC2 death, and inflammatory cell recruitment [51,52]. In autoinflammatory disorders, uncontrolled IFN-gamma production is a main feature of the pathophysiology. This could explain the accelerated parenchymal destruction process (cysts) despite minor ECM deposition [16]. The alveolar collapse and the coalescence of thickened alveolar septal walls explain the reticulation bands characteristic of ILD. However, even in these inflammatory disorders, less alveolar distortion and ECM deposition is observed in children than in adult fibrosis.

In children, PF is observed at an earlier point of the pathophysiologic process. The differences that are observed compared with adult and elderly patients could thus be related to the absence of aging phenomena. Indeed, innate and adaptative immune response and wound-healing processes become less effective with increasing age. Immunosenescence affects all cell types involved in the immunomodulation process, including epithelial cells and macrophages. With age, epithelial cells become more susceptible to cellular stress, including ER and oxidative stress, which leads to chronic inflammation, abnormal remodeling, and uncontrolled apoptotic pathways [53]. Immunosenescence also induces profound modifications in fibroblast function [54]. This is well illustrated by skin wound healing in the fetus, which is characterized by complete regeneration of the skin and the absence of any scar formation. This capacity for scarless repair is lost with age and the regeneration of the tissue architecture is achieved through the formation of a scar that exceeds the wound bed. The slowing of wound healing with age may be related to changes in the activity of various regulatory factors such as fibroblast growth factor, vascular growth factor, epithelial growth factor, and transforming growth factor (TGF)-beta production [55]. Other potential mechanisms of lung reconstruction following injury during childhood include stem cells. Stem cells are the self-renewing, primitive, undifferentiated, and multipotent source of multiple cell lineages [56-59]. They are critical during development, and their lung pool, as in other organs, decrease with age, explaining the limited tissue regeneration that occurs in adults $[60,61]$. In addition, bone-marrow-derived stem cells (BMSCs) are known to be able to engraft in various organs, including the lung, and to differentiate into epithelial cells [62]. The ability of immortality of embryonic stem cells disappears with age, and they also show a gradual decrease of telomere length $[63,64]$. Shorter telomeres are found in individuals with lung disease, and telomerase mutations are reported to be associated with familial IPF. With increasing age, the limited life span of cells may thus result from a limited cell replicative ability in response to various stresses, including DNA damage, oxidants, and telomere erosion $[65,66]$. Senescent mechanisms are likely to be 
of minor impact in infant and childhood lungs, but the difficulty of lung biopsy explains why no study is available.

\section{Treatments in Pediatric PF}

Defining children's PF characteristics is of major importance to develop targeted therapies. It seems that pediatric ILD is more responsive to therapeutic strategies than adult ILD [67,68]. However, due to the rarity of the disease, treatment options are based on limited experiences from small series, cases reports, and local habits of the reference centers without any appropriately designed clinical trial. Moreover, it is likely that on a growing lung, treatments that are used can interfere with the fibrosing evolution of the lung. Corticosteroids are currently the preferred choice for its anti-inflammatory effects, with an initial daily oral dose of $1-2 \mathrm{mg} / \mathrm{kg} / \mathrm{day}$ of prednisolone and/or a pulsed intravenous monthly dose of 10-30 mg/kg/day for 3 days consecutively of methylprednisolone [69]. Corticosteroids are highly effective when the cellular quota is predominant and less so when ECM deposition is predominant. Corticosteroids also display effects on lung maturation. This property is well known in preterm infants, and antenatal corticosteroids are widely used to enhance lung maturation and surfactant synthesis by AEC2 in mothers at risk of premature delivery to reduce the risk of respiratory distress syndrome [70]. It has been associated with beneficial effects in almost all chILD forms, including surfactant disorders $[3,21,69,71,72]$, hemosiderosis [73,74], but also in severe forms of neuroendocrine cell hyperplasia of infancy (NEHI) [75].

An alternative to steroids is hydroxychloroquine (HCQ), which has a recommended dose of $6-10 \mathrm{mg} / \mathrm{kg} /$ day orally [76-78]. The decision as to which agent to use may be guided by the local habits of the clinicians or the lung biopsy findings, with a preference for steroids in case of a large amount of cellular desquamation and inflammation and for HCQ if increased amounts of collagen representing prefibrotic change are found [76]. In case of severe disease, steroids and HCQ may be combined. Besides its effect against malaria, HCQ displays various mechanisms of immune action, such as interference with inhibition of lysosomal proteolysis, chemotaxis, phagocytosis, antigen presentation, decreasing of various cytokines, increase of interleukins, and matrix metalloproteinase inhibition [76]. In surfactant disorders, it has been shown that HCQ may inhibit the intracellular processing of the precursor protein of SP-C [79]. HCQ accumulates in blood cells and cells of various organs including the lungs, explaining why despite low plasma levels, tissue levels can be more than 10 times higher. It has been suggested that this property could enhance the cellular effect of other medications, such as corticosteroids, without increasing their systemic side effects.

In situations of the inefficiency of steroids and HCQ, but also as a first intention treatment case of autoinflammatory disorders, other drugs such as immunosuppressive, immunomodulatory, or cytotoxic agents, such as azathioprine, cyclophosphamide, cyclosporine, or methotrexate, may be used $[16,38,39,42]$.

Other therapeutic options include macrolides. Indeed, these antibiotics have been shown to display a number of anti-inflammatory and immunomodulatory actions. Of interest is the ability of macrolides to accumulate in parenchymal cells, including epithelial cells and phagocytes $[20,80]$.

In the future, antifibrotic therapies that are used in adult cases of IPF will certainly be proposed for children ILD with fibrosing features. They include pirfenidone, a compound with anti-inflammatory and antifibrotic properties, and nintedanib, a tyrosine kinase inhibitor initially developed as an antitumor agent, with further activity against fibroblasts through inhibition of several growth factors [81,82]. The use of such therapies in children will require better defining the criteria of PF in the pediatric population. However, despite eventual long-term side effects, it could be anticipated that targeting multiple pathophysiologic pathways could be of benefit to avoid the fibrosing evolution of ILD in children and adults $[50,83,84]$. 


\section{Outcome of PF in Childhood}

Limited information is available in the literature about the evolution of pediatric patients with PF. This is partly due to the fact that the PF definition is not consensual and these patients may represent a very small proportion of the chILD population. chILD evolution is very heterogeneous, and despite being incurable in some cases, long-term survival has been described. Our experience of histologically proven pediatric PF seems to be in favor of a severe evolution towards terminal respiratory failure in childhood (lung transplantation or death). However, when comparing patients 3-5 (Table 2), who had very similar clinical, radiological, and histologic presentations, we observed a radically different evolution of patient 5, who recovered clinically in a few years, with no clue for explaining such a disparity. Thus, despite a global poor prognosis, further studies of long-term follow-up of pediatric patients with PF are needed.

\section{Conclusions}

PF in children is poorly described and refers to a small proportion of chILD. The aggregation of national cohorts into international networks will allow pediatricians, radiologists, and pathologists to get to a consensual definition of PF criteria in children. This preliminary evaluation of available information on pediatric PF highlights that the term "pulmonary fibrosis" may have a different meaning in children than in adults, with more cellular recruitment, less collagen deposition, and less parenchymal destruction (Figure 2). Thus, unlike in adults, the hypothesis that PF is a scar state with few fibrosis lesions in children allows for considering the significant beneficial effects of antifibrotic therapies.

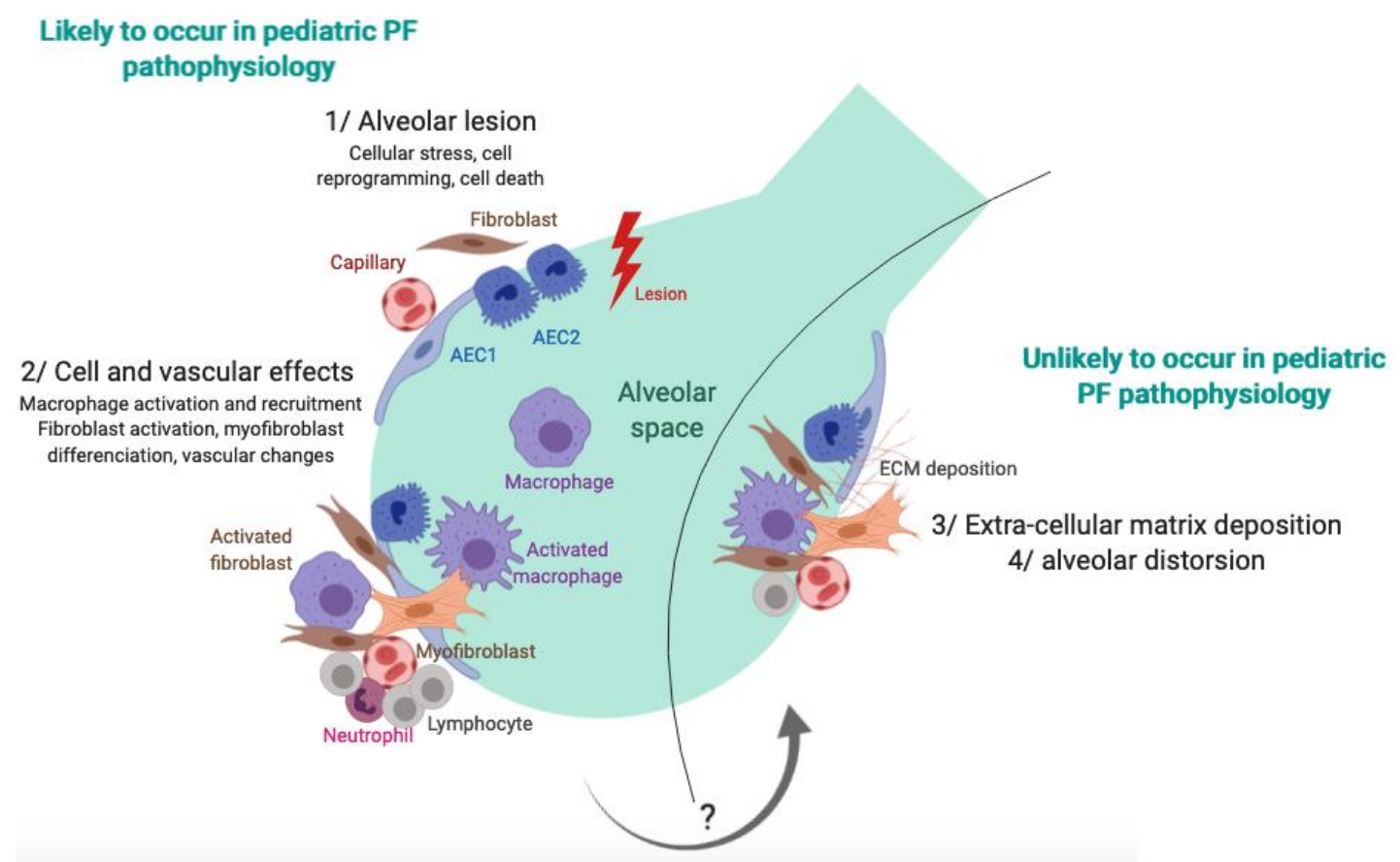

Figure 2. Potential pathophysiology pathway of pulmonary fibrosis in children. Repeated alveolar lesions' effects on AECs and alveolar macrophages are likely to be observed in children and adult pulmonary fibrosis, leading to a cellular NSIP pattern. The chance of an evolution toward an adult PF pattern with more fibroblastic activation and extracellular matrix deposition remains unknown.

Author Contributions: Writing-Original Draft Preparation, N.N.; supervision, A.C.; provided expertise on lung histopathology, A.C.H.; provided expertise on lung imaging, C.S. and H.D.1.P.; diagnosis and follow-up of the described patients, reviewed the manuscript, N.N., C.S., G.T., L.B., C.D., E.M., S.P., P.-L.L., H.D.1.P., A.C.H., A.C.

Funding: This research received no external funding. 
Acknowledgments: We thank the Assistance Publique Hôpitaux de Paris; Sorbonne Université, Paris, France; and the national networks for rare lung diseases: Centre de référence des maladies respiratoires rares (RespiRare), Centre de référence des maladies pulmonaires rares (OphaLung), and Filière de soins pour les maladies respiratoires rares (RespiFIL). The ILD cohort was developed in collaboration with the Rare Cohort Disease (RaDiCo)-ILD project (RaDiCo is funded by the French National Research Agency under the specific programme "Investments for the Future", Cohort grant agreement ANR-10-COHO-0003), the FP7-305653-child-EU project, and the COST Action European network for translational research in children's and adult interstitial lung disease (COST-ILD) project (CA16125). We thank for their financial support in our research projects: the Institut National de la Santé et la Recherche Médicale (INSERM); the Legs Poix from the Chancellerie des Universités (grants 2013 no. 1305, 2014 no. 1405, 2015 no. 1015, 2016 no. 2077, and 2017 no. DP2017/1860), Paris; the European Union's Seventh Framework Program (FP7-ChILD-EU 2007-2013) under grant agreement no. 305653; as well as the patient organizations Respirer c'est Grandir and Belleherbe Association.

Conflicts of Interest: The authors declare no conflict of interest.

\section{References}

1. Deutsch, G.H.; Young, L.R.; Deterding, R.R.; Fan, L.L.; Dell, S.D.; Bean, J.A.; Brody, A.S.; Nogee, L.M.; Trapnell, B.C.; Langston, C.; et al. Diffuse lung disease in young children: Application of a novel classification scheme. Am. J. Respir. Crit. Care Med. 2007, 176, 1120-1128. [CrossRef] [PubMed]

2. Clement, A.; Nathan, N.; Epaud, R.; Fauroux, B.; Corvol, H. Interstitial lung diseases in children. Orphanet J. Rare Dis. 2010, 5, 22. [CrossRef] [PubMed]

3. Kurland, G.; Deterding, R.R.; Hagood, J.S.; Young, L.R.; Brody, A.S.; Castile, R.G.; Dell, S.; Fan, L.L.; Hamvas, A.; Hilman, B.C.; et al. An official American Thoracic Society clinical practice guideline: Classification, evaluation, and management of childhood interstitial lung disease in infancy. Am. J. Respir. Crit. Care Med. 2013, 188, 376-394. [CrossRef] [PubMed]

4. Rice, A.; Tran-Dang, M.-A.; Bush, A.; Nicholson, A.G. Diffuse lung disease in infancy and childhood: Expanding the chILD classification. Histopathology 2013, 63, 743-755. [CrossRef] [PubMed]

5. Griese, M.; Irnstetter, A.; Hengst, M.; Burmester, H.; Nagel, F.; Ripper, J.; Feilcke, M.; Pawlita, I.; Gothe, F.; Kappler, M.; et al. Categorizing diffuse parenchymal lung disease in children. Orphanet J. Rare Dis. 2015, 10, 122. [CrossRef]

6. Nathan, N.; Berdah, L.; Borensztajn, K.; Clement, A. Chronic interstitial lung diseases in children: Diagnosis approaches. Expert Rev. Respir. Med. 2018, 12, 1051-1060. [CrossRef] [PubMed]

7. Lederer, D.J.; Martinez, F.J. Idiopathic Pulmonary Fibrosis. N. Engl. J. Med. 2018, 378, 1811-1823. [CrossRef]

8. Mueller-Mang, C.; Grosse, C.; Schmid, K.; Stiebellehner, L.; Bankier, A.A. What every radiologist should know about idiopathic interstitial pneumonias. Radiographics 2007, 27, 595-615. [CrossRef]

9. Raghu, G.; Remy-Jardin, M.; Myers, J.L.; Richeldi, L.; Ryerson, C.J.; Lederer, D.J.; Behr, J.; Cottin, V.; Danoff, S.K.; Morell, F; et al. Diagnosis of Idiopathic Pulmonary Fibrosis. An Official ATS/ERS/JRS/ALAT Clinical Practice Guideline. Am. J. Respir. Crit. Care Med. 2018, 198, e44-e68. [CrossRef]

10. Hashisako, M.; Fukuoka, J. Pathology of Idiopathic Interstitial Pneumonias. Clin. Med. Insights Circ. Respir. Pulm. Med. 2015, 9, 123-133. [CrossRef]

11. Raghu, G.; Collard, H.R.; Egan, J.J.; Martinez, F.J.; Behr, J.; Brown, K.K.; Colby, T.V.; Cordier, J.-F.; Flaherty, K.R.; Lasky, J.A.; et al. An official ATS/ERS/JRS/ALAT statement: Idiopathic pulmonary fibrosis: Evidence-based guidelines for diagnosis and management. Am. J. Respir. Crit. Care Med. 2011, 183, 788-824. [CrossRef] [PubMed]

12. Mulugeta, S.; Nureki, S.-I.; Beers, M.F. Lost after translation: Insights from pulmonary surfactant for understanding the role of alveolar epithelial dysfunction and cellular quality control in fibrotic lung disease. Am. J. Physiol. Lung Cell Mol. Physiol. 2015, 309, L507-L525. [CrossRef] [PubMed]

13. Dishop, M.K. Paediatric interstitial lung disease: Classification and definitions. Paediatr. Respir. Rev. 2011, 12, 230-237. [CrossRef] [PubMed]

14. Manali, E.D.; Legendre, M.; Nathan, N.; Kannengiesser, C.; Coulomb L'Hermine, A.; Tsiligiannis, T.; Tomos, P.; Griese, M.; Borie, R.; Clement, A.; et al. Bi-allelic missense ABCA3 mutations in a patient with children's ILD who reached adulthood. ERJ Open Res. 2019, in press. [CrossRef] [PubMed]

15. Nikolaidou, P.; Charocopos, E.; Anagnostopoulos, G.; Lazopoulou, D.; Kairis, M.; Lourida, A.; Tzoumakas, K.; Tsiligiannis, T. Cellular Interstitial Pneumonitis in Children: Response to Hydroxychloroquine Treatment in Two Cases. Pediatr. Asthma Allergy Immunol. 2003, 16, 45-51. [CrossRef] 
16. Picard, C.; Thouvenin, G.; Kannengiesser, C.; Dubus, J.-C.; Jeremiah, N.; Rieux-Laucat, F.; Crestani, B.; Belot, A.; Thivolet-Béjui, F.; Secq, V.; et al. Severe Pulmonary Fibrosis as the First Manifestation of Interferonopathy (TMEM173 Mutation). Chest 2016, 150, e65-e71. [CrossRef] [PubMed]

17. Wang, Y.; Kuan, P.J.; Xing, C.; Cronkhite, J.T.; Torres, F.; Rosenblatt, R.L.; DiMaio, J.M.; Kinch, L.N.; Grishin, N.V.; Garcia, C.K. Genetic defects in surfactant protein A2 are associated with pulmonary fibrosis and lung cancer. Am. J. Hum. Genet. 2009, 84, 52-59. [CrossRef] [PubMed]

18. Nathan, N.; Giraud, V.; Picard, C.; Nunes, H.; Dastot-Le Moal, F.; Copin, B.; Galeron, L.; de Ligniville, A.; Kuziner, N.; Reynaud-Gaubert, M.; et al. Germline SFTPA1 mutation in familial idiopathic interstitial pneumonia and lung cancer. Hum. Mol. Genet. 2016, 25, 1457-1467. [CrossRef] [PubMed]

19. Ota, C.; Kimura, M.; Kure, S. ABCA3 mutations led to pulmonary fibrosis and emphysema with pulmonary hypertension in an 8-year-old girl. Pediatr. Pulmonol. 2016, 51, E21-E23. [CrossRef] [PubMed]

20. Thouvenin, G.; Nathan, N.; Epaud, R.; Clement, A. Diffuse parenchymal lung disease caused by surfactant deficiency: Dramatic improvement by azithromycin. BMJ Case Rep. 2013, 2013, bcr2013009988. [CrossRef]

21. Thouvenin, G.; Abou Taam, R.; Flamein, F.; Guillot, L.; Le Bourgeois, M.; Reix, P.; Fayon, M.; Counil, F.; Depontbriand, U.; Feldmann, D.; et al. Characteristics of disorders associated with genetic mutations of surfactant protein C. Arch. Dis. Child. 2010, 95, 449-454. [CrossRef] [PubMed]

22. Whitsett, J.A.; Wert, S.E.; Weaver, T.E. Alveolar surfactant homeostasis and the pathogenesis of pulmonary disease. Annu. Rev. Med. 2010, 61, 105-119. [CrossRef] [PubMed]

23. Kröner, C.; Wittmann, T.; Reu, S.; Teusch, V.; Klemme, M.; Rauch, D.; Hengst, M.; Kappler, M.; Cobanoglu, N.; Sismanlar, T.; et al. Lung disease caused by ABCA3 mutations. Thorax 2017, 72, 213-220. [CrossRef] [PubMed]

24. Van Moorsel, C.H.; van Oosterhout, M.F.; Barlo, N.P.; de Jong, P.A.; van der Vis, J.J.; Ruven, H.J.; van Es, H.W.; van den Bosch, J.M.; Grutters, J.C. Surfactant protein C mutations are the basis of a significant portion of adult familial pulmonary fibrosis in a dutch cohort. Am. J. Respir. Crit. Care Med. 2010, 182, 1419-1425. [CrossRef] [PubMed]

25. Cottin, V.; Reix, P.; Khouatra, C.; Thivolet-Béjui, F.; Feldmann, D.; Cordier, J.-F. Combined pulmonary fibrosis and emphysema syndrome associated with familial SFTPC mutation. Thorax 2011, 66, 918-919. [CrossRef] [PubMed]

26. Ono, S.; Tanaka, T.; Ishida, M.; Kinoshita, A.; Fukuoka, J.; Takaki, M.; Sakamoto, N.; Ishimatsu, Y.; Kohno, S.; Hayashi, T.; et al. Surfactant protein C G100S mutation causes familial pulmonary fibrosis in Japanese kindred. Eur. Respir. J. 2011, 38, 861-869. [CrossRef] [PubMed]

27. Epaud, R.; Delestrain, C.; Louha, M.; Simon, S.; Fanen, P.; Tazi, A. Combined pulmonary fibrosis and emphysema syndrome associated with ABCA3 mutations. Eur. Respir. J. 2014, 43, 638-641. [CrossRef] [PubMed]

28. Coghlan, M.A.; Shifren, A.; Huang, H.J.; Russell, T.D.; Mitra, R.D.; Zhang, Q.; Wegner, D.J.; Cole, F.S.; Hamvas, A. Sequencing of idiopathic pulmonary fibrosis-related genes reveals independent single gene associations. BMJ Open Respir. Res. 2014, 1, e000057. [CrossRef] [PubMed]

29. Doubková, M.; Staňo Kozubík, K.; Radová, L.; Pešová, M.; Trizuljak, J.; Pál, K.; Svobodová, K.; Réblová, K.; Svozilová, H.; Vrzalová, Z.; et al. A novel germline mutation of the SFTPA1 gene in familial interstitial pneumonia. Hum. Genome Var. 2019, 6, 12. [CrossRef]

30. Van Moorsel, C.H.M.; Ten Klooster, L.; van Oosterhout, M.F.M.; de Jong, P.A.; Adams, H.; Wouter van Es, H.; Ruven, H.J.T.; van der Vis, J.J.; Grutters, J.C. SFTPA2 Mutations in Familial and Sporadic Idiopathic Interstitial Pneumonia. Am. J. Respir. Crit. Care Med. 2015, 192, 1249-1252. [CrossRef]

31. Abou Taam, R.; Jaubert, F.; Emond, S.; Le Bourgeois, M.; Epaud, R.; Karila, C.; Feldmann, D.; Scheinmann, P.; de Blic, J. Familial interstitial disease with I73T mutation: A mid- and long-term study. Pediatr. Pulmonol. 2009, 44, 167-175. [CrossRef]

32. Thomas, A.Q.; Lane, K.; Phillips, J.; Prince, M.; Markin, C.; Speer, M.; Schwartz, D.A.; Gaddipati, R.; Marney, A.; Johnson, J.; et al. Heterozygosity for a surfactant protein C gene mutation associated with usual interstitial pneumonitis and cellular nonspecific interstitial pneumonitis in one kindred. Am. J. Respir. Crit. Care Med. 2002, 165, 1322-1328. [CrossRef] [PubMed]

33. Cameron, H.S.; Somaschini, M.; Carrera, P.; Hamvas, A.; Whitsett, J.A.; Wert, S.E.; Deutsch, G.; Nogee, L.M. A common mutation in the surfactant protein $C$ gene associated with lung disease. J. Pediatr. 2005, 146, 370-375. [CrossRef] 
34. Guillot, L.; Epaud, R.; Thouvenin, G.; Jonard, L.; Mohsni, A.; Couderc, R.; Counil, F.; de Blic, J.; Taam, R.A.; Le Bourgeois, M.; et al. New surfactant protein $C$ gene mutations associated with diffuse lung disease. J. Med. Genet. 2009, 46, 490-494. [CrossRef]

35. Campo, I.; Zorzetto, M.; Mariani, F.; Kadija, Z.; Morbini, P.; Dore, R.; Kaltenborn, E.; Frixel, S.; Zarbock, R.; Liebisch, G.; et al. A large kindred of pulmonary fibrosis associated with a novel ABCA3 gene variant. Respir. Res. 2014, 15, 43. [CrossRef] [PubMed]

36. Jovien, S.; Borie, R.; Doummar, D.; Clement, A.; Nathan, N. Respiratory Distress, Congenital Hypothyroidism and Hypotonia in a Newborn. Respiration 2016, 92, 188-191. [CrossRef] [PubMed]

37. Nattes, E.; Lejeune, S.; Carsin, A.; Borie, R.; Gibertini, I.; Balinotti, J.; Nathan, N.; Marchand-Adam, S.; Thumerelle, C.; Fauroux, B.; et al. Heterogeneity of lung disease associated with NK2 homeobox 1 mutations. Respir. Med. 2017, 129, 16-23. [CrossRef] [PubMed]

38. Jeremiah, N.; Neven, B.; Gentili, M.; Callebaut, I.; Maschalidi, S.; Stolzenberg, M.-C.; Goudin, N.; Frémond, M.-L.; Nitschke, P.; Molina, T.J.; et al. Inherited STING-activating mutation underlies a familial inflammatory syndrome with lupus-like manifestations. J. Clin. Investig. 2014, 124, 5516-5520. [CrossRef] [PubMed]

39. Liu, Y.; Jesus, A.A.; Marrero, B.; Yang, D.; Ramsey, S.E.; Montealegre Sanchez, G.A.; Tenbrock, K.; Wittkowski, H.; Jones, O.Y.; Kuehn, H.S.; et al. Activated STING in a vascular and pulmonary syndrome. N. Engl. J. Med. 2014, 371, 507-518. [CrossRef]

40. Watkin, L.B.; Jessen, B.; Wiszniewski, W.; Vece, T.J.; Jan, M.; Sha, Y.; Thamsen, M.; Santos-Cortez, R.L.P.; Lee, K.; Gambin, T.; et al. COPA mutations impair ER-Golgi transport and cause hereditary autoimmune-mediated lung disease and arthritis. Nat. Genet. 2015, 47, 654-660. [CrossRef] [PubMed]

41. Noorelahi, R.; Perez, G.; Otero, H.J. Imaging findings of Copa syndrome in a 12-year-old boy. Pediatr. Radiol. 2018, 48, 279-282. [CrossRef] [PubMed]

42. Tsui, J.L.; Estrada, O.A.; Deng, Z.; Wang, K.M.; Law, C.S.; Elicker, B.M.; Jones, K.D.; Dell, S.D.; Gudmundsson, G.; Hansdottir, S.; et al. Analysis of pulmonary features and treatment approaches in the COPA syndrome. ERJ Open Res. 2018, 4, 00017. [CrossRef] [PubMed]

43. Lynch, D.A.; Sverzellati, N.; Travis, W.D.; Brown, K.K.; Colby, T.V.; Galvin, J.R.; Goldin, J.G.; Hansell, D.M.; Inoue, Y.; Johkoh, T.; et al. Diagnostic criteria for idiopathic pulmonary fibrosis: A Fleischner Society White Paper. Lancet Respir. Med. 2018, 6, 138-153. [CrossRef]

44. Nathan, N.; Corvol, H.; Amselem, S.; Clement, A. Biomarkers in Interstitial lung diseases. Paediatr. Respir. Rev. 2015, 16, 219-224. [CrossRef] [PubMed]

45. Vancheri, C.; Cottin, V.; Kreuter, M.; Hilberg, O. IPF, comorbidities and management implications. Sarcoidosis Vasc. Diffus. Lung Dis. 2015, 32 (Suppl. S1), 17-23.

46. Kumar, A.; Cherian, S.V.; Vassallo, R.; Yi, E.S.; Ryu, J.H. Current Concepts in Pathogenesis, Diagnosis, and Management of Smoking-Related Interstitial Lung Diseases. Chest 2018, 154, 394-408. [CrossRef] [PubMed]

47. Sisson, T.H.; Mendez, M.; Choi, K.; Subbotina, N.; Courey, A.; Cunningham, A.; Dave, A.; Engelhardt, J.F.; Liu, X.; White, E.S.; et al. Targeted injury of type II alveolar epithelial cells induces pulmonary fibrosis. Am. J. Respir. Crit. Care Med. 2010, 181, 254-263. [CrossRef] [PubMed]

48. Huber, M.A.; Kraut, N.; Beug, H. Molecular requirements for epithelial-mesenchymal transition during tumor progression. Curr. Opin. Cell Biol. 2005, 17, 548-558. [CrossRef] [PubMed]

49. Bringardner, B.D.; Baran, C.P.; Eubank, T.D.; Marsh, C.B. The role of inflammation in the pathogenesis of idiopathic pulmonary fibrosis. Antioxid. Redox Signal. 2008, 10, 287-301. [CrossRef]

50. Ahluwalia, N.; Shea, B.S.; Tager, A.M. New therapeutic targets in idiopathic pulmonary fibrosis. Aiming to rein in runaway wound-healing responses. Am. J. Respir. Crit. Care Med. 2014, 190, 867-878. [CrossRef]

51. Maguire, J.A.; Mulugeta, S.; Beers, M.F. Multiple ways to die: Delineation of the unfolded protein response and apoptosis induced by Surfactant Protein C BRICHOS mutants. Int. J. Biochem. Cell Biol. 2012, 44, 101-112. [CrossRef] [PubMed]

52. Mulugeta, S.; Nguyen, V.; Russo, S.J.; Muniswamy, M.; Beers, M.F. A surfactant protein C precursor protein BRICHOS domain mutation causes endoplasmic reticulum stress, proteasome dysfunction, and caspase 3 activation. Am. J. Respir. Cell Mol. Biol. 2005, 32, 521-530. [CrossRef] [PubMed]

53. Brandenberger, C.; Mühlfeld, C. Mechanisms of lung aging. Cell Tissue Res. 2017, 367, 469-480. [CrossRef] [PubMed] 
54. Gurtner, G.C.; Callaghan, M.J.; Longaker, M.T. Progress and potential for regenerative medicine. Annu. Rev. Med. 2007, 58, 299-312. [CrossRef] [PubMed]

55. Komi-Kuramochi, A.; Kawano, M.; Oda, Y.; Asada, M.; Suzuki, M.; Oki, J.; Imamura, T. Expression of fibroblast growth factors and their receptors during full-thickness skin wound healing in young and aged mice. J. Endocrinol. 2005, 186, 273-289. [CrossRef] [PubMed]

56. Moore, K.A.; Lemischka, I.R. Stem cells and their niches. Science 2006, 311, 1880-1885. [CrossRef] [PubMed]

57. Gurtner, G.C.; Chapman, M.A. Regenerative Medicine: Charting a New Course in Wound Healing. Adv. Wound Care (N. Rochelle) 2016, 5, 314-328. [CrossRef] [PubMed]

58. Chen, F.; Fine, A. Stem Cells in Lung Injury and Repair. Am. J. Pathol. 2016, 186, 2544-2550. [CrossRef]

59. Schilders, K.A.A.; Eenjes, E.; van Riet, S.; Poot, A.A.; Stamatialis, D.; Truckenmüller, R.; Hiemstra, P.S.; Rottier, R.J. Regeneration of the lung: Lung stem cells and the development of lung mimicking devices. Respir. Res. 2016, 17, 44. [CrossRef]

60. Pomerantz, J.; Blau, H.M. Nuclear reprogramming: A key to stem cell function in regenerative medicine. Nat. Cell Biol. 2004, 6, 810-816. [CrossRef]

61. Chen, Y.-W.; Huang, S.X.; de Carvalho, A.L.R.T.; Ho, S.-H.; Islam, M.N.; Volpi, S.; Notarangelo, L.D.; Ciancanelli, M.; Casanova, J.-L.; Bhattacharya, J.; et al. A three-dimensional model of human lung development and disease from pluripotent stem cells. Nat. Cell Biol. 2017, 19, 542-549. [CrossRef] [PubMed]

62. Liang, Y.; Yin, C.; Lu, X.I.; Jiang, H.; Jin, F. Bone marrow mesenchymal stem cells protect lungs from smoke inhalation injury by differentiating into alveolar epithelial cells via Notch signaling. J. Biosci. 2019, 44, 2. [CrossRef] [PubMed]

63. Liu, T.; Gonzalez De Los Santos, F.; Zhao, Y.; Wu, Z.; Rinke, A.E.; Kim, K.K.; Phan, S.H. Telomerase reverse transcriptase ameliorates lung fibrosis by protecting alveolar epithelial cells against senescence. J. Biol. Chem. 2019, 294, 8861-8871. [CrossRef] [PubMed]

64. Koliakos, G. Stem Cells and Aging. Rejuvenation Res. 2017, 20, 4-8. [CrossRef] [PubMed]

65. Armanios, M.Y.; Chen, J.J.-L.; Cogan, J.D.; Alder, J.K.; Ingersoll, R.G.; Markin, C.; Lawson, W.E.; Xie, M.; Vulto, I.; Phillips, J.A.; et al. Telomerase mutations in families with idiopathic pulmonary fibrosis. N. Engl. J. Med. 2007, 356, 1317-1326. [CrossRef] [PubMed]

66. Alder, J.K.; Chen, J.J.; Lancaster, L.; Danoff, S.; Su, S.C.; Cogan, J.D.; Vulto, I.; Xie, M.; Qi, X.; Tuder, R.M.; et al. Short telomeres are a risk factor for idiopathic pulmonary fibrosis. Proc. Natl. Acad. Sci. USA 2008, 105, 13051-13056. [CrossRef] [PubMed]

67. Clement, A.; ERS Task Force. Task force on chronic interstitial lung disease in immunocompetent children. Eur. Respir. J. 2004, 24, 686-697. [CrossRef] [PubMed]

68. Clement, A.; Eber, E. Interstitial lung diseases in infants and children. Eur. Respir. J. 2008, 31, $658-666$. [CrossRef]

69. Bush, A.; Cunningham, S.; de Blic, J.; Barbato, A.; Clement, A.; Epaud, R.; Hengst, M.; Kiper, N.; Nicholson, A.G.; Wetzke, M.; et al. European protocols for the diagnosis and initial treatment of interstitial lung disease in children. Thorax 2015, 70, 1078-1084. [CrossRef]

70. Roberts, D.; Brown, J.; Medley, N.; Dalziel, S.R. Antenatal corticosteroids for accelerating fetal lung maturation for women at risk of preterm birth. Cochrane Database Syst. Rev. 2017, 3, CD004454. [CrossRef]

71. Hime, N.J.; Zurynski, Y.; Fitzgerald, D.; Selvadurai, H.; Phu, A.; Deverell, M.; Elliott, E.J.; Jaffe, A. Childhood interstitial lung disease: A systematic review. Pediatr. Pulmonol. 2015, 50, 1383-1392. [CrossRef] [PubMed]

72. Nathan, N.; Borensztajn, K.; Clement, A. Genetic causes and clinical management of pediatric interstitial lung diseases. Curr. Opin. Pulm. Med. 2018, 24, 253-259. [CrossRef] [PubMed]

73. Taytard, J.; Nathan, N.; de Blic, J.; Fayon, M.; Epaud, R.; Deschildre, A.; Troussier, F.; Lubrano, M.; Chiron, R.; Reix, P.; et al. New insights into pediatric idiopathic pulmonary hemosiderosis: The French RespiRare $\left({ }^{\circledR}\right)$ cohort. Orphanet J. Rare Dis. 2013, 8, 161. [CrossRef] [PubMed]

74. Alimi, A.; Taytard, J.; Abou Taam, R.; Houdouin, V.; Forgeron, A.; Lubrano Lavadera, M.; Cros, P.; Gibertini, I.; Derelle, J.; Deschildre, A.; et al. Pulmonary hemosiderosis in children with Down syndrome: A national experience. Orphanet J. Rare Dis. 2018, 13, 60. [CrossRef] [PubMed]

75. Nassar, A.A.; Jaroszewski, D.E.; Helmers, R.A.; Colby, T.V.; Patel, B.M.; Mookadam, F. Diffuse idiopathic pulmonary neuroendocrine cell hyperplasia: A systematic overview. Am. J. Respir. Crit. Care Med. 2011, 184, 8-16. [CrossRef] [PubMed] 
76. Braun, S.; Ferner, M.; Kronfeld, K.; Griese, M. Hydroxychloroquine in children with interstitial (diffuse parenchymal) lung diseases. Pediatr. Pulmonol. 2015, 50, 410-419. [CrossRef] [PubMed]

77. Klay, D.; Hoffman, T.W.; Harmsze, A.M.; Grutters, J.C.; van Moorsel, C.H.M. Systematic review of drug effects in humans and models with surfactant-processing disease. Eur. Respir. Rev. 2018, 27, 170135. [CrossRef] [PubMed]

78. Williamson, M.; Wallis, C. Ten-year follow up of hydroxychloroquine treatment for ABCA3 deficiency. Pediatr. Pulmonol. 2014, 49, 299-301. [CrossRef]

79. Vece, T.J.; Fan, L.L. Diagnosis and management of diffuse lung disease in children. Paediatr. Respir. Rev. 2011, 12, 238-242. [CrossRef]

80. Guillot, L.; Tabary, O.; Nathan, N.; Corvol, H.; Clement, A. Macrolides: New therapeutic perspectives in lung diseases. Int. J. Biochem. Cell Biol. 2011, 43, 1241-1246. [CrossRef]

81. Aravena, C.; Labarca, G.; Venegas, C.; Arenas, A.; Rada, G. Pirfenidone for Idiopathic Pulmonary Fibrosis: A Systematic Review and Meta-Analysis. PLOS ONE 2015, 10, e0136160.

82. Richeldi, L.; Cottin, V.; du Bois, R.M.; Selman, M.; Kimura, T.; Bailes, Z.; Schlenker-Herceg, R.; Stowasser, S.; Brown, K.K. Nintedanib in patients with idiopathic pulmonary fibrosis: Combined evidence from the TOMORROW and INPULSIS $\left({ }^{\circledR}\right)$ trials. Respir. Med. 2016, 113, 74-79. [CrossRef] [PubMed]

83. Lauby, C.; Boelle, P.-Y.; Abou Taam, R.; Bessaci, K.; Brouard, J.; Dalphin, M.-L.; Delacourt, C.; Delestrain, C.; Deschildre, A.; Dubus, J.-C.; et al. Health-related quality of life in infants and children with interstitial lung disease. Pediatr. Pulmonol. 2019, 54, 828-836. [CrossRef] [PubMed]

84. Breuer, O.; Schultz, A. Side effects of medications used to treat childhood interstitial lung disease. Paediatr. Respir. Rev. 2018, 28, 68-79. [CrossRef] [PubMed]

(C) 2019 by the authors. Licensee MDPI, Basel, Switzerland. This article is an open access article distributed under the terms and conditions of the Creative Commons Attribution (CC BY) license (http://creativecommons.org/licenses/by/4.0/). 